\title{
Shock Tube and Modeling Study of the Monomethylamine Oxidation at High Temperature
}

\author{
Kuan Soo Shin ${ }^{*}$ and Sang Jo Yoo \\ Department of Chemistry, Soongsil Cniversin; Seoul 156-743, Korea \\ Received October 30.2003
}

\begin{abstract}
The ignition of monomethylamine was studied in reflected shock waves over the temperature range of 1255 $1579 \mathrm{~K}$ and the pressure range of 1.04-1.51 bar. The ignition delay time was measured by the sudden increase of pressure profile and the radiation emitted by $\mathrm{OH}$ radicals. The relationship between the ignition delay time and the concentrations of monomethylamine and oxygen was determined in the form of mass-action expressions with an Arrhenius temperature dependence. In contrast to the behavior observed in hydrocarbons. monomethylamine acts to accelerate rather than inhibit its own ignition. And numerical modeling of the ignition of $\mathrm{CH}_{3} \mathrm{NH}_{2}$ has also been carried out to test the several kinetic mechanisms.
\end{abstract}

Key Words : Monomethylamine, Ignition, Shock tube. Nitrogen oxides

\section{Introduction}

Nitrogen-containing fuels are responsible for a significant part of NO emissions from practical combustion systems. The problen of NO formation from fuel nitrogen becontes particularly inportant for the incineration of nitrogencontaining materials. Incineration of the nitrogen-containing compound will produce oxides of nitrogen such as $\mathrm{NO}$. $\mathrm{NO}_{3}$. and possibly $\mathrm{N}_{3} \mathrm{O}$. The nitrogen oxides contribute to the formation of photochemical smog. and $\mathrm{N}_{3} \mathrm{O}$ depletes ozone in the stratosphere and is a greenhouse gas. $\mathrm{NO}$ is known to be formed in a variety of ways: (1) "Thermal NO" (Zeldovich. $1946)^{\mathrm{l}}$ is primarily a consequence of high flame temperatures: (2) "Prompt NO" (Fenimore, 1976)" is generated in fuel-rich parts of flames: (3) the " $\mathrm{N}_{2} \mathrm{O}$ mechanism" (Wolfrum, 1972 3 ; Malte and Pratt, 1974 ) can be important in high-pressure flames; (4) "Fuel NO" (Fenimore, 1976)" results from converting nitrogen-containing compounds in the fuel into NO; and (5) the NNH mechanisn (Bozzelli and Dean. 1995$)^{5}$ is active in flame fronts where high atom concentrations appear.

There are several methods for the reduction of nitrogen oxides formed as unwanted by-products in technical conbustion processes called the selective catalytic reduction (SCR) and selective non-catalytic reduction (SNCR) methods. In SNCR systemis. anmonia (Thermal DeNOx). ${ }^{6}$ urea (NOxOUT), ${ }^{7}$ and cyanuric acid (RapreNOx) ${ }^{8}$ are used as reductants. In these processes, NO removal occurs through a reaction with $\mathrm{NH}_{2}$ radical. which is derived from SNCR agents through reaction with $\mathrm{OH}$ and $\mathrm{O}$. Since these methods can only be generated at temperatures over $1000 \mathrm{~K}$. $\mathrm{NO}$ reduction is difficult at temperatures blow $1000 \mathrm{~K}$. Monomethylamine $\left(\mathrm{CH}_{3} \mathrm{NH}_{2}\right)$ is an alternative substance producing $\mathrm{NH}_{2}$ radicals in the thermal decomposition and, it could be used for the reduction of $\mathrm{NO}^{10}$ Because the derivation of $\mathrm{NH}_{2}$ from anines begins at temperatures around $600 \mathrm{~K}^{1]}$

The high temperature pyrolysis of monomethylamine has been investigated by Higashihara et $a .^{12}$ Klatt et $a .^{13}$ and Votsmeier et al. ${ }^{14}$ using various shock tube techniques. Higashihara et al. ${ }^{12}$ was studied by IR laser kinetic absorption spectroscopy behind reflected shock waves with over the temperature range from $1400 \mathrm{~K}$ to $1820 \mathrm{~K}$. Klatt et $\mathrm{al}^{13}$ studied the decomposition of monometlylamine behind incident shock waves in the temperature range from $1750 \mathrm{~K}$ to $2450 \mathrm{~K}$. Recently, Votsmaier et $a .^{14}$ studied themal decomposition of monomethy lamine using laser absorption diagnostic and kinetic shock tube studies. They measured $\mathrm{NH}_{2}$ radical concentration profiles with sensitive laser absorption diagnostic for $\mathrm{NH}_{2}$ at a detection wavelength of $16739.90 \mathrm{~cm}^{-1}$ and computationally simulated with detailed kinetics. In contrast with the monomethylanine pyrolysis, the monomethylamine oxidation behind shock waves, however, was not much studied experimentally except for Hwang et $a l^{15}$ and Lifshitz et $a l^{16}$ Hwang et $a l^{15}$ studied monomethylamine oxidation by IR laser kinetic absorption spectroscopy behind reflected shock waves over the temperature range $1260-1600 \mathrm{~K}$ and modeled with a 141 reaction mechanism. Lifshitz et al ${ }^{\text {lit }}$ studied the ignition of monomethylamine in reflected shock waves over the temperature range from 1000 to $1300 \mathrm{~K}$. Kantak et al ${ }^{17}$ recently studied the oxidation of monomethylamine in a flow reactor over the temperature range of $600-1400 \mathrm{~K}$ and assembled a reaction mechanism describing the monomethylamine conversion under these conditions.

Monomethylamine as the simplest primary organic amine is the model compound to study the "Fuel $\mathrm{NO}^{\circ}$ mechanism converting nitrogen-containing fuel to $\mathrm{NO}$ and it also acts as an SNCR agent by producing $\mathrm{NH}_{2}$ radical to reduce $\mathrm{NO}$. In order to understand more details of the role of monomethylamine under combustion enviromment. more experimental and modeling studies are needed. In this investigation. the ignition delay times of $\mathrm{CH}_{3} \mathrm{NH}_{2}-\mathrm{O}_{2}-\mathrm{Ar}$ mixtures were measured over the temperature range from $1255 \mathrm{~K}$ to $1579 \mathrm{~K}$, and a correlation between ignition delay times and concentrations of $\mathrm{CH}_{2} \mathrm{NH}_{2}$ and $\mathrm{O}_{2}$ was investigated. Several kinetic mecha- 
nisms for $\mathrm{CH}_{3} \mathrm{NH}_{2}$ oxidation at high temperature have also been tested by the computer simulation.

\section{Experimental Section}

The experiments were performed behind reflected shock waves in stainless-steel shock tube which was described in detailed elsewhere. ${ }^{2-26}$ The apparatus consists of a $514 \mathrm{~cm}$ (6.02 cm i.d.) 304 stainless-steel tube separated from the He driver gas chamber by a unscored aluminium diaphragnm with $0.1 \mathrm{~mm}$ thickness. The tube is routinely pumped between experiments to $<10^{-7}$ torr by turbo molecular pump (Varian, 969-9002) system. The velocity of the shock wave was measured with five pressure transducers (PCB 113A21) connected to four digital timer/counters (Fluke PM6666). The temperature and pressure in the reflected shock wave regime were calculated from this velocity. ${ }^{2 \cdot-26}$

The ignition was measured by the sudden increase of pressure profile and $\mathrm{OH}$ emission intensity. The pressure measurements were made using a pressure transducer (PCB $113 \mathrm{~A} 21)$ which was located at $1.0 \mathrm{~cm}$ from the reflecting surface. The characteristic ultraviolet emission from $\mathrm{OH}$ radical species at $306.7 \mathrm{~nm}$ was monitored using a photomultiplier tube (ARC DA-781) with a band path filter (Andower, $308 \mathrm{~mm}$ ) through the sapphire window which was mounted flush at $1.0 \mathrm{~cm}$ from the end plate of shock tube. The window was masked to $1 \mathrm{~mm}$ slit width in order to reduce emission intensity and improve the time resolution of the system. Both traces were fed into a digital oscilloscope (HP 45601A).

The compositions of the mixtures are given in Table 1. The equivalence ratio was varied to examine the composition dependences on the ignition delay time. $\mathrm{CH}_{3} \mathrm{NH}_{2}\left(98^{-\%} \%\right.$, Aldrich), $\mathrm{O}_{2}(99,99 \%$. Dongmin) and $\operatorname{Ar}(99.9993 \%$, Donga) were used without further purification. He $(99.9995 \%$, Dongmin) was used as a driver gas. Test gas mixtures were prepared manometrically and then used after keeping for over 24 hours in aluminium cylinders. The initial pressure $\left(P_{1}\right)$ was fixed to 30 torr and the shock velocity could be controlled by changing the pressure of He driver gas. The measurements covered a temperature range $\left(\mathrm{I}_{5}\right)$ of 1255 $1579 \mathrm{~K}$ and a pressure range $\left(P_{5}\right)$ of 1.04-1.5I bar behind reflected shock waves. The measured ignition delay times ranged from 66 to $1373 \mu \mathrm{s}$.

Table 1. The experimental conditions for $\mathrm{CH}_{3} \mathrm{NH}_{2}-\mathrm{O}_{2}-\mathrm{Ar}$ mixtures

\begin{tabular}{|c|c|c|c|c|c|c|}
\hline & \multicolumn{3}{|c|}{ Compositions $(\%)$} & \multirow{2}{*}{$\tau(\mu \sec )$} & \multirow{2}{*}{$\mathrm{T}_{5}(\mathrm{~K})$} & \multirow{2}{*}{$P_{5}$ (bar) } \\
\hline & $\mathrm{CH}_{3} \mathrm{NH}_{2}$ & $\mathrm{O}_{2}$ & $\mathrm{Ar}$ & & & \\
\hline Mixture 1 & 2.0 & 5.5 & 92.5 & $66-781$ & $1324-1538$ & $1.13-1.44$ \\
\hline Mixture 2 & 2.0 & 2.8 & 95.2 & $110-816$ & $1390-1579$ & $1.18-1.45$ \\
\hline Mixture 3 & 1.0 & 5.5 & 93.5 & $138-1137$ & $1321-1488$ & $1.04-1.27$ \\
\hline Mixture 4 & 2.0 & 11.0 & 87.0 & $76-1373$ & $1255-1486$ & $1.07-1.45$ \\
\hline Mixture 5 & 4.0 & 5.5 & 90.5 & $101-1230$ & $1282-1475$ & $1.19-1.51$ \\
\hline Mixture 6 & 3.0 & 8.3 & 88.7 & $85-844$ & $1288-1485$ & $1.15-1.48$ \\
\hline
\end{tabular}

\section{Results and Discussion}

Figure 1 shows a typical oscilloscope trace for pressure and $\mathrm{OH}$ emission profiles measured at $1.0 \mathrm{~cm}$ from the reflecting end plate. The upper trace records the total pressure and the lower trace the $\mathrm{OH}$ emission. The ignition delay time ( $\tau$ ) was defined as the time interval between the arrival of the reflected shock wave front and the onset of an ignition. The ignition delay time derived from the $\mathrm{OH}$ emission is almost the same as that derived from the pressure profile. The effects of $\mathrm{CH}_{3} \mathrm{NH}_{2}$ and $\mathrm{O}_{2}$ concentrations on the ignition delays are shown in Figure 2.

A correlation between ignition delays and concentrations was customarily summarized in the form of mass-action expressions with an Arrhenius temperature dependence. ${ }^{27}$ Multiple regression analysis was employed to obtain the best-fit parameters. This procedure gave

$$
\begin{aligned}
& \tau- 6.29 \times 10^{-12} \exp \left(44 \mathrm{kcal} \mathrm{mol}^{-1} / R T\right) \\
& \times\left[\mathrm{CH}_{3} \mathrm{NH}_{2}\right]^{-6.25}\left[\mathrm{O}_{2}\right]^{-(1.86}
\end{aligned}
$$

where $\tau$ and the concentrations are given in $\mathrm{sec}$ and $\mathrm{mol} / \mathrm{\textrm {cm } ^ { 3 }}$,

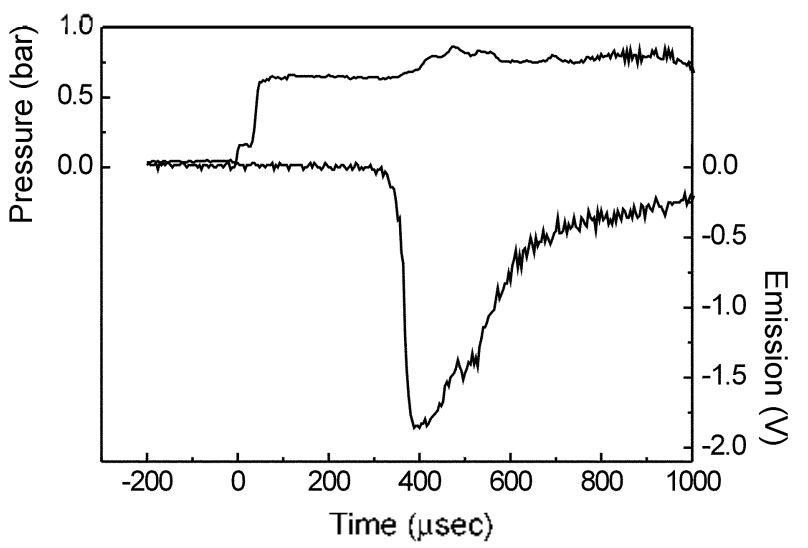

Figure 1. Typical experimental record showing pressure (upper) and $\mathrm{OH}$ cmission (lower). Experimental conditions were $P_{1}=30$ torr. $P_{5} \quad 1.33$ har. and $T_{5} \quad 1425 \mathrm{~K}$ in mixlure 4.

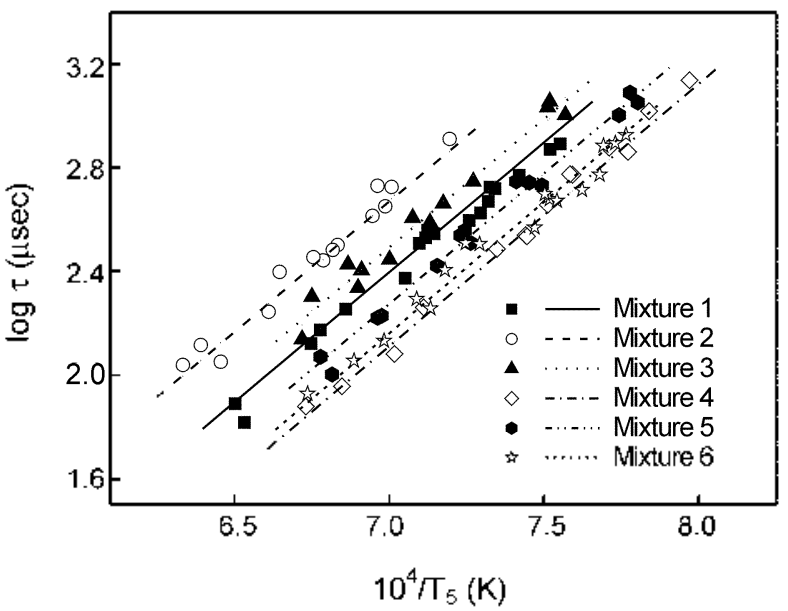

Figure 2. lgnition delay times for the mixtures shown in Table 2. Lines represent the least squares fits for the corresponding mixtures using the expression in the text. 


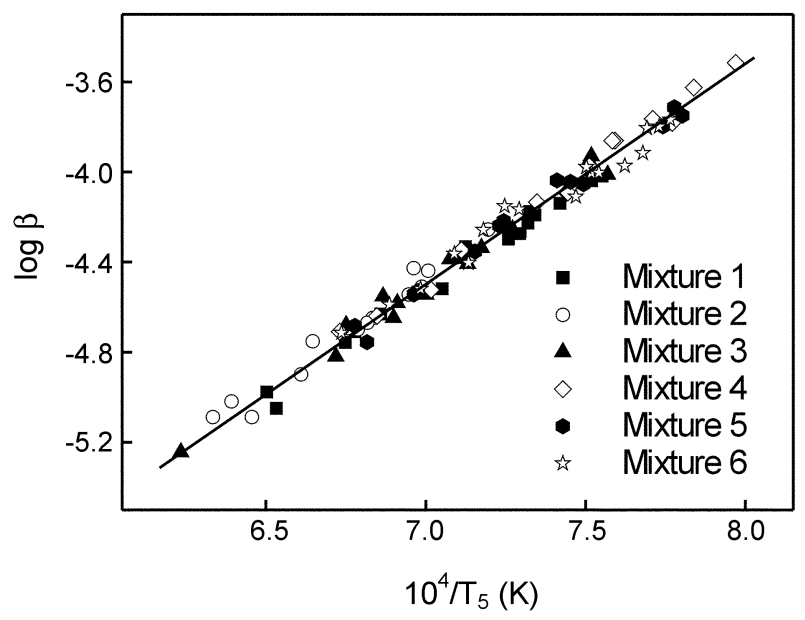

Figure 3. A plon of $\log \beta w \cdot 10^{+} \mathrm{T}$; for all mixlures: $\beta$ $\tau\left\{\left[\mathrm{CII}_{3} \mathrm{NH}_{2}\right]^{0.23}\left[\mathrm{O}_{2}\right]^{0.80}\right\}_{\text {. }}$.

respectively. It is worth noting that the parameters are valid only for the specific ranges of pressure, temperature and concentrations over which ignition delays were measured. The reliability of this empirical formula was tested by plotting all data as $\log \left(\tau\left\{\left[\mathrm{CH}_{3} \mathrm{NH}_{2}\right]^{-0.23}\left[\mathrm{O}_{2}\right]^{-0.86}\right\}\right)$ vs. $10^{4} / \mathrm{T}_{5}$. As shown in Figure 3, all points lie close to a single line. The power dependence of monomethylamine indicates self-accelerating effect; the ignition delay times decrease by increasing the concentration of monomethylamine. And, the power dependence of oxygen indicates the promotion effect: the ignition delay times decrease by increasing the concentration of oxygen, ln this investigation, the argon dependence on the ignition of monomethylamine was not obtained because the concentration of argon in our mixtures was not varied much.

At first glance, $\mathrm{CH}_{3} \mathrm{NH}_{2}$ would be expected to ignite in a manner analogous to ethane $\left(\mathrm{C}_{2} \mathrm{H}_{6}\right)$. Both decompose thermally by central bond breaking to form relatively unreactive radicals and both yield radicals upon $\mathrm{H}$-abstraction that decompose to $\mathrm{H}$-atoms and more slowly igniting species, $\mathrm{C}_{2} \mathrm{H}_{4}$ and $\mathrm{CH}_{2} \mathrm{NH}$. In fact, $\mathrm{CH}_{3} \mathrm{NH}_{2}$ and $\mathrm{C}_{2} \mathrm{H}_{6}$ ignite differently. The power dependence of the ignition delay on the small hydrocarbon concentration is usually positive. ${ }^{2 k-70}$ It indicates that the hydrocarbon fuel inhibits the ignition process. For most hydrocarbon fuels $(\mathrm{RH})$, the reaction $\mathrm{H}+$ $\mathrm{RH} \rightarrow \mathrm{H}_{2}+\mathrm{R}$ competes with chain branching reaction $\mathrm{H}+$ $\mathrm{O}_{2} \rightarrow \mathrm{OH}+\mathrm{O}$ for hydrogen atoms and is responsible for the positive power dependence on fuel concentration. In contrast with small hydrocarbons, the power dependence of ignition delay on $\mathrm{CH}_{3} \mathrm{NH}_{2}$ concentration shows negative dependence $(-0.23)$, which means that $\mathrm{CH}_{3} \mathrm{NH}_{2}$ itself has the promotion effect in the ignition process.

In order to understand more details on monomethylamine oxidation at high temperature, the numerical modeling study was also tested using various reaction mechanisms. The reaction mechanism of $\mathrm{CH}_{3} \mathrm{NH}_{2}$ oxidation usually could be divided into three parts; (1) the first part of the mechanism is mainly composed of the initial reactions concerning the $\mathrm{CH}_{3} \mathrm{NH}_{2}$ consumption, (2) the second part is constructed
Table 2. Mechanisms for the oxidation of monomethylaminc at high temperature

\begin{tabular}{|c|c|c|}
\hline Mechanism & $\begin{array}{l}\text { No. of } \\
\text { species }\end{array}$ & $\begin{array}{l}\text { No. of } \\
\text { reactions }\end{array}$ \\
\hline Mechanism 1: Kantak et al. ${ }^{17}$ & 65 & 350 \\
\hline Mechanism 2: Hizang et al $\left.\right|^{15}$ & 44 & 141 \\
\hline Mechanism 3: GRI 3.0 $0^{18}+$ Hwang of tl. $^{15}$ & 59 & 371 \\
\hline Mechanism 4: Kantak ef al. $^{17}-$ Daan \& Bozzelli' & 65 & 350 \\
\hline Mechanism 5: Dcan \& Bozzel]j ${ }^{20}+$ GRl $3.0^{18}$ & 73 & 424 \\
\hline Mechanism 6: Coda et al. ${ }^{18}+$ Dean \& Bozze) $\left.]\right]^{201}$ & 64 & 410 \\
\hline
\end{tabular}

using NO formation and destruction reactions, (3) the rest part of the mechanism is consisted of hydrocarbon oxidation reactions concerning the $\mathrm{C}_{1}$ or $\mathrm{C}_{2}$ hydrocarbon species. The mechanisms used in this modeling study of monomethylamine oxidation are listed in Table 2 . The reaction mechanism proposed by Hwang et $a l^{15}$ consists of 141 elementary reactions with 44 species. Kantak et al. ${ }^{17}$ also reported their mechanism composed of 350 elementary reactions and 65 species. In mechanism 3, a large set of reactions describing $C_{1}$ and $C_{2}$ bydrocarbon and $\mathrm{NO}$ chemistry was taken from the GRl 3.0 mechanism ${ }^{18}$ and the $\mathrm{CH}_{3} \mathrm{NH}_{2}$ reactions were taken from a mechanism proposed by Hwang ef $a l^{15}$ The mechanism proposed by Coda ef al. ${ }^{10}$ involves 57 species in 353 elementary gas-phase reactions. In Coda et al ${ }^{(9)}$ mechanism, the oxidation reactions of $\mathrm{C}_{1} / \mathrm{C}_{2}$ hydrocarbons, $\mathrm{HCN}$, and $\mathrm{NH}_{3}$, as well as the reactions between hydrocarbons $\left(\mathrm{CH}_{i}, \mathrm{HCCO}\right)$ and nitrogen species $\left(\mathrm{NO}, \mathrm{NH}_{\mathrm{in}} \mathrm{N}_{2}\right)$ were included. Dean and Bozzelli ${ }^{20}$ recently reviewed the reactions involving nitrogen species. In order to construct the $\mathrm{CH}_{3} \mathrm{NH}_{2}$ consumption submechanism, 65 elementary reactions were taken from Dean and Bozzelli ${ }^{70}$ mechanism in the mechanisms 4,5 and 6 in Table 2.

Computations of modeling were carried out using Sandia Chemkin [I] code. ${ }^{22}$ Thermodynamic data were obtained from Chemkin thermodynamic data base. ${ }^{2 l}$ The rate constants for the reverse reactions were calculated with the forward rate constants and the appropriate equilibrium constants. As shown in Figure 4 , the calculated ignition delay times using the mechanism 6 (Coda $e t a^{19}+$ Dean and Bozzelli ${ }^{20}$ ), which consists of 410 elementary reactions with 64 species, shows the best agreement with the observed ones for all mixtures.

In the complex reaction mechanism, all of elementary reactions do not contribute equally to the ignition delay times of monomethylamine, but some of them may do essentially. In oder to find the sensitive reactions, logarithmic sensitivity analysis, ${ }^{\text {"1 }}$ listed in lable 3 , was calculated using the mechanism 6. Sensitivity analysis was performed on all reactions by increasing forward rate constant, multiplying a rate constant by factor of 2 .

$$
S_{y}=\frac{\Delta \log \tau_{1}}{\Delta \log k_{j}}
$$

where, $\tau_{i}$ is ignition delay time at condition of $i$. And $k_{i}$ is rate constant of $j$ the elementary reaction. $S_{i j}$ is logarithmic 

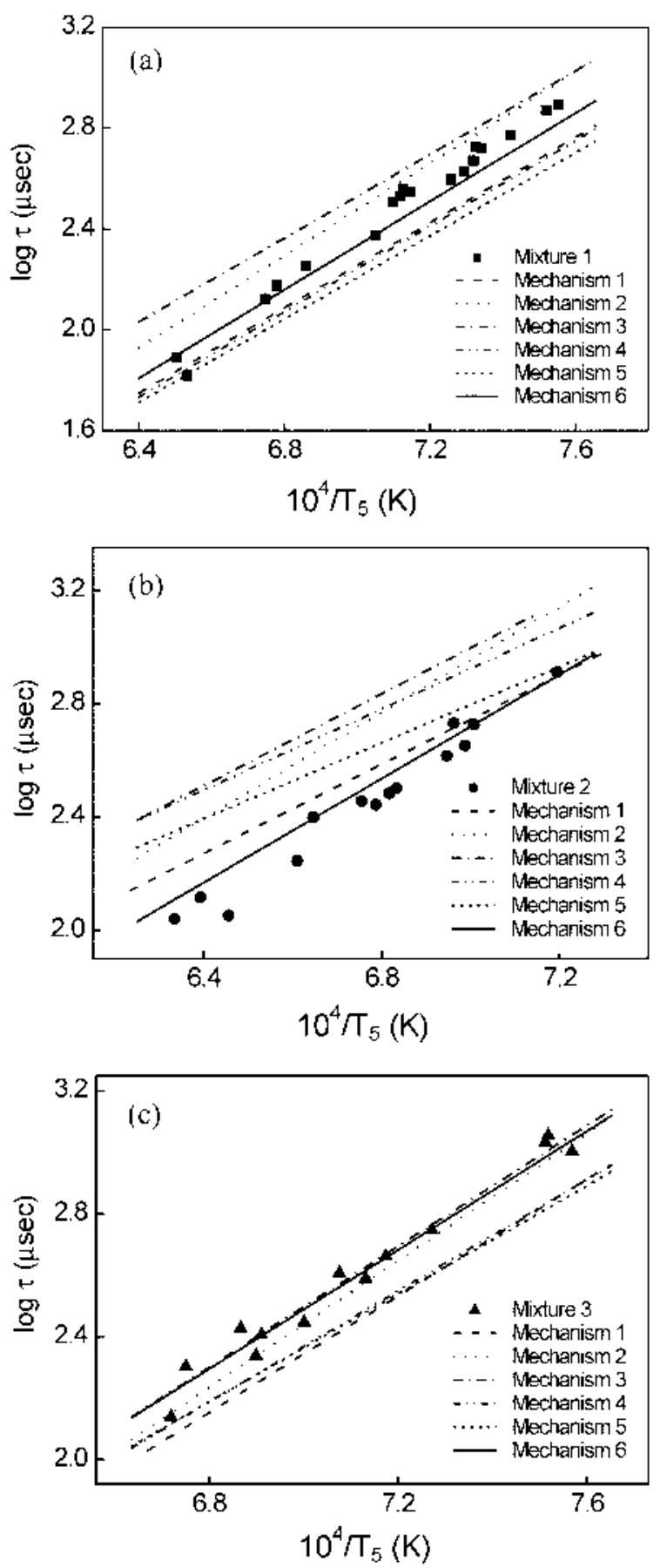

Figure 4. Comparison of observed innition delay times (symbols) with calculated ones (lines) using the $\mathrm{Cl}_{3} \mathrm{NH}_{2}$ oxidation mechanisms. (a) mixturs 1 (near stoichiometric), (b) mixture 2 (ficl rich), (c) mixture 3 (fuel lean).

sensitivity. The sensitivity analysis shows the following reactions are important in the ignition of $\mathrm{CH}_{3} \mathrm{NH}_{2}$.

$$
\begin{aligned}
& \mathrm{CH}_{2} \mathrm{NH}_{2}+\mathrm{O}_{2} \rightarrow \mathrm{CH}_{3} \mathrm{O}+\mathrm{HNO} \\
& \mathrm{O}+\mathrm{OH} \rightarrow \mathrm{H} \rightarrow \mathrm{O}_{2} \\
& \mathrm{CH}_{3} \mathrm{NH}_{2}+\mathrm{OII} \rightarrow \mathrm{CH}_{3} \mathrm{NII} \cdot \mathrm{H}_{2} \mathrm{O}
\end{aligned}
$$

Reactions (1) and (3) are the initiation reactions and reaction (2) is the chain branching reaction. These three reactions are important in the ignition process. As shown in the Table 3.
Table 3. logarithmic sensitivity values of ignition delay time for

\begin{tabular}{|c|c|c|c|}
\hline Reaction & Mixture 3 & Mixture 1 & Mixture 5 \\
\hline $\mathrm{CH}_{2} \mathrm{NH}_{2}+\mathrm{O}_{2} \rightarrow \mathrm{CH}_{3} \mathrm{O}+\mathrm{HNO}$ & -0.29374 & -0.22214 & -0.16288 \\
\hline $\mathrm{O}+\mathrm{OH} \rightarrow \mathrm{H}+\mathrm{O}_{2}$ & -0.29124 & -0.22854 & -0.25593 \\
\hline $\mathrm{Cll}_{3} \mathrm{NH}_{2}+\mathrm{OII} \rightarrow \mathrm{Cl}_{3} \mathrm{NII}+\mathrm{II}_{2} \mathrm{O}$ & -0.25348 & -0.25026 & -0.26427 \\
\hline $\mathrm{Cl}_{2} \mathrm{NH}_{2}+\mathrm{O}_{2} \rightarrow \mathrm{II}_{2} \mathrm{CNII}+1 \mathrm{HO}_{2}$ & -0.1116 & -0.12241 & -0.14309 \\
\hline $\mathrm{CH}_{3} \mathrm{NH}+\mathrm{O}_{2} \rightarrow \mathrm{H}_{2} \mathrm{C} \mathrm{NH}+\mathrm{HO}_{2}$ & -0.08216 & -0.11432 & -0.16115 \\
\hline $\mathrm{HO}_{2}+\mathrm{H} \rightarrow \mathrm{OH}+\mathrm{OH}$ & -0.08001 & -0.07188 & -0.09352 \\
\hline $\mathrm{CH}_{2} \mathrm{NH}_{2}+\mathrm{H}_{2} \mathrm{O}_{2} \rightarrow \mathrm{CH}_{3} \mathrm{NH}_{2}-\mathrm{HO}_{2}$ & -0.07141 & -0.10413 & -0.13882 \\
\hline $\mathrm{CH}_{3} \mathrm{NH}+\mathrm{H}_{2} \mathrm{O}_{2} \rightarrow \mathrm{CH}_{3} \mathrm{NH}_{2}+\mathrm{HO}_{2}$ & -0.06927 & -0.09613 & -0.13117 \\
\hline $\mathrm{NO}+\mathrm{llO}_{2} \rightarrow . \mathrm{NO}_{2}+\mathrm{OII}$ & -0.05543 & -0.06562 & -0.09849 \\
\hline $\mathrm{H}_{2} \mathrm{NO}+\mathrm{H} \rightarrow \mathrm{NH}_{2}+\mathrm{OH}$ & -0.04873 & -0.06823 & -0.10097 \\
\hline $\mathrm{HCNH}+\mathrm{O}_{2} \rightarrow \mathrm{HC} \cdot \mathrm{V}+\mathrm{HO}_{2}$ & -0.04698 & -0.08343 & -0.14309 \\
\hline $\mathrm{NH}_{2}+\mathrm{NO} \rightarrow \mathrm{NNH}+\mathrm{OH}$ & -0.04417 & -0.04649 & -0.06167 \\
\hline $\mathrm{HCO}+\mathrm{O}_{2} \rightarrow \mathrm{CO}^{-\mathrm{HO}_{2}}$ & -0.04032 & -0.07031 & -0.14309 \\
\hline $\mathrm{CH}_{3} \mathrm{NH}_{2}+\mathrm{H} \rightarrow \mathrm{CH}_{3} \mathrm{NH}+\mathrm{H}_{2}$ & -0.03683 & -0.04855 & -0.05925 \\
\hline $\mathrm{NI}_{3}+\mathrm{OH} \rightarrow \mathrm{NH}_{2}+\mathrm{II}_{2} \mathrm{O}$ & 0.03226 & 0.03002 & 0.05468 \\
\hline $\mathrm{HO}_{2}+\mathrm{II} \rightarrow \mathrm{I}_{2}+\mathrm{O}_{2}$ & 0.03525 & 0.03343 & 0.05765 \\
\hline $\mathrm{Cl}_{3} \mathrm{NH}_{2}+\mathrm{II} \rightarrow \mathrm{CH}_{2} \mathrm{NII}_{2}+\mathrm{II}_{2}$ & 0.04977 & 0.06372 & 0.11952 \\
\hline $\mathrm{HO}_{2}+\mathrm{OH} \rightarrow \mathrm{H}_{2} \mathrm{O}+\mathrm{O}_{2}$ & 0.08352 & 0.07131 & 0.07466 \\
\hline $\mathrm{CH}_{3} \mathrm{NH}+\mathrm{O}_{2} \rightarrow \mathrm{CH}_{3} \mathrm{O}+\mathrm{HNO}$ & 0.08448 & 0.12474 & 0.17473 \\
\hline $\mathrm{CH}_{3} \mathrm{NH}_{2}+\mathrm{OH} \rightarrow \mathrm{CH}_{2} \mathrm{NH}_{2}+\mathrm{H}_{2} \mathrm{O}$ & 0.16913 & 0.16345 & 0.18906 \\
\hline
\end{tabular}
mixtures 3 (lean). I (stoichiometric). and 5 (rich) at $T_{5}=1400 \mathrm{~K}$. Sensitivities less than 0.02 are not listed

however. the special features of the firel aecelerating effice in the ignition of monomethylamine come from the following reactions, the lomation reactions of $\mathrm{IIO}$, and the reaction of $\mathrm{IIO}_{2}+\mathrm{II} \rightarrow \mathrm{OII}+\mathrm{OII}$.

$$
\begin{aligned}
& \mathrm{CH}_{2} \mathrm{NH}_{2}+\mathrm{O}_{2} \rightarrow \mathrm{H}_{2} \mathrm{CNH}+\mathrm{HO}_{2} \\
& \mathrm{CH}_{3} \mathrm{NH}+\mathrm{O}_{2} \rightarrow \mathrm{H}_{2} \mathrm{CNH}+\mathrm{HO}_{2} \\
& \mathrm{HO}_{2}+\mathrm{H} \rightarrow \mathrm{OH}+\mathrm{OH}
\end{aligned}
$$

lormation of $\mathrm{IIO}_{2}$ by 1 -atom transfers to $\mathrm{O}_{2}$. followed by subsequent reaction of $11 \mathrm{O}_{2}$ with 11 to two $\mathrm{OH}$ radicals. are the steps that provide the aceelerating ellect of monomethylamine.

\section{Conclusions}

In the present study. a comprehensive shock tube and modeling investigation was performed on the ignition of $\mathrm{CH}_{3} \mathrm{NH}_{2}-\mathrm{O}_{2}-\mathrm{Ar}$ mixtures in the temperature range of $1255-$ $1579 \mathrm{~K}$ and the pressure range of 1.04-1.51 bar. The ignition delay limes were measured by the increase of pressure and $\mathrm{OH}$ emission. A correlation between ignition delay times and concentrations of monomethylamine and oxygen could be summarized in the following empirical formula.

$$
\begin{aligned}
\tau= & 6.29 \times 10^{-12} \exp \left(\left.44 \mathrm{kcal} \mathrm{mol}\right|^{-1 / R T}\right) \\
& {\left[\mathrm{CH}_{3} \mathrm{NH}_{2}\right]^{-0.23}\left[\mathrm{O}_{2}\right]^{-0.86}\left(\mathrm{~mol} / \mathrm{cm}^{3}\right)^{1.109} \mathrm{sec} }
\end{aligned}
$$

In contrast to the behavior observed in small hydrocarbons. which usually inhibit their own ignition. monomethylamine acts to aceclerate rather than inhibit its own ignition. Several kinetic mechanisms proposed for monomethylamine oxidation at high temperatures have been 
tested by the computer simulation. It was found that the ignition delay times calculated from the mechanism 6 in Table 2 were in good agreement with our experimental data. A model study showed that the formation reactions of $\mathrm{HO}_{2}$ followed by the reaction of $\mathrm{HO}_{2}+\mathrm{H} \rightarrow \mathrm{OH}+\mathrm{OH}$ are the steps that provide the accelerating effect of monomethylamine.

Acknowledgment. This work was supported by the Soongsil University Research Fund.

\section{References}

1. Zeldovich. Y. B. Acta Phisicochimica L.R.S.S. 1946. 21. 577.

2. Fenimore. C. P. Combustion and Flame 1976. 26. 249.

3. Wolfrum. I. Chentie Ingenteur Technik 1972. H. 656 .

4. Malte, P. C.: Pratt. D. T. Contbust. Sici. Tech 1974 9.221

5. Bozzelli. J. W.: Dean, A. M. Int. J. Chent. Kinet 1995. 27. 1097.

6. Miller. J. A.: Branch. M. C.: Kee. R. J. Combustion and Flame 1981. 43.81.

7. Arand. J. K.: Muzio. L. J.: Sotter. J. G. U. S. Patent +1982.208. 386.

8. Carton, J. A.: Siebers. D. L. ASME J. Fluids Eng 1989. $111,387$.

9. Yoshihara. Y: Ikegani. M: Mine, N. Trants, Japan Soc. Mech. Eng. Series B 1990. 56. 845.

10. Yoshihara. Y: Tanaka. T. Trons. Japan Soc. Mech. Eng. Series B 1995. 61. 408

11. Miller J. A.; Bowman. C. T. Prog. Energe Combust Sci. 1989, I5. 287

12. Higashihara. T: Gardiner. W. C.. Ir: Hwang, S. M. J. Phws Chent. 1987. 91.1900

13. Klatt. M.: Spindler. B.: Wagner. H. Gg. Z. Phns. Chem. 1995. 191. 241 .

14. Votsmeier M: Song. S: Davidson, D. F: Hanson. R. K. Int. J. Chem. Kinet 1999. 31, 323
15. Hwang. S. M.: Higashihara. T.: Shin. K. S.: Gardiner. W. C.. Jr. $J$. Phus. Chem. 1990. 94. 2883

16. Lifshitz, A; Bidani. M.: Carroll, H. F.: Hwang, S. M.; Fu, P. Y: Shin. K. S.: Gardiner, W. C. Jr. Conbustion and Flane 1991. 86. 229 .

17. Kantak. M. V: Manrique. K. S. De:: Aglave. R. H.: Hesketh. R. P. Combustion and Flane 1997. 108. 235.

18. GRI-Mechanism 3.0 is available by World Wide Web using the http euler.berkelevedugri mech version30 text30 htm1: 1999

19. Coda Zabetta. E.: Kilpinen. P.: Hupa. M.: Stahl. K.: Leppalahti. J.:

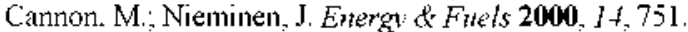

20. Dean. A. M.: Bozzelli. J. W. In Gas-Phase Combustion Chemisny: Gardiner. W. C.. Tr.. Ed.: Springer-Verlag: New York. 2000): p 125.

21. Kee. R. I.: Rupley. F. M.: Miller. I. A. The Chemhin Thenmodnamic Date base Sandia National Laboratories Report SAND87-8215B: 1990.

22. Kee, R. J.; Rupley. F. M.; Meeks, E.; Miller. J. A. Chenthin-III; A Fortran Chemical Kinetics Package for the Anatysis of Gas-Phase Chemical and Plasma Kinetics. Sandia National Laboratories Report SAND96-8216: 1996.

23. Lutz. A. E.; Kee, R. J.: Miller, J. A. Sandia National Laboratoris Report NO. SAND87-8248: 1991.

24. Jee, S. B.; Kim, W. K, Shin, K. S. J. Korean Chem. Soc. 1999, 3 . 156

25. Jee. S. B.: Kim. K. Y.: Shin. K. S. Bull. Korean Chem Soc. 2000. 21. 1015 .

26. Kim. W. K. Shin, K. S. J. Korean Chem Soc. 1997. 1 . 600

27. Tsang. W. Lifshitz. A. Anmol Reniew of Physical Chentistry $1990 .+1,559$

28. Jee. S. B.: Kim. W. K.: Shin. K. S. J. Koman Chem. Soc 1999. 43. 156.

29. Shim. S. B.: Teong. S. H.: Shin. K. S. J. Koman Chem. Soc. 1998. 42. 575 .

30. Kim. K. Y. Shin, K. S. Bull. Korem Chem. Soc. $2001,22,303$.

31. Lissianski, V. V: Zamansky. V. M: Gardiner, W. C., Jr. In GasPhase Combustion Chemistry. Gardiner. W. C.. Ir.. Ed.: SpringerVerlag: New York. 2000): 1. 